\title{
Os olhos e o verbo em Lavoura arcaica
}

\section{Hugo J. C. Retamar}

\begin{abstract}
Resumo: Analiso a obra Lavoura Arcaica de Raduan Nassar penetrando no contexto da família de imigrantes árabes que têm sua coluna vertebral na figura do pai, detentor do poder sobre ela, através da força do verbo repetido e reiterado ao redor da mesa. $\mathrm{Na}$ trama, o verbo do pai é semeado em cada um dos integrantes da família. Os olhos, em contraponto, são os propulsores da revolta, da mudança, e são os espelhos da alma, representando o estado de pureza dos personagens. À luz dessa noção de coletividade o pai impinge a cada integrante da família um destino imutável de obediência e de conformismo, porém André, o personagem centro da narrativa, quebra a circularidade da palavra do pai. $\mathrm{O}$ presente trabalho analisa, então, a trajetória da família através das representações referentes ao poder da palavra e dos olhos na obra de Raduan Nassar.
\end{abstract}

Palavras-chave: Olhos; Vontade; Verbo; Palavra; Poder.

\begin{abstract}
In this study I analyze the work Lavoura Arcaica, by Raduan Nasar, looking at the context of a Arab descendants' family, which has its core in the figure of the father, who holds power over his family through the strength of the repeated and restated verb at the table. In Nasar's plot the father's verb is sown in each of the family members. The eyes, in contrast, are the revolt and change "propellers", they are mirrors of the soul, once they represent the characters' state of purity. In light of this collective notion the father imposes to each family member an unchangeable destiny of obedience and conformism. However, Andre, the central character, breaks away with the circularity in the father's word. This paper analyses, then, the family's history through the representations regarding the power of the word and the eyes in the work of Raduan Nasar.
\end{abstract}

Keywords: Eyes; Will; Verb; Word; Power.

Os olhos no teto, a nudez dentro do quarto; róseo, azul ou violáceo, o quarto é inviolável; o quarto é individual, é um mundo, quarto catedral, onde, nos intervalos da angústia, se colhe, de um áspero caule, na palma da mão, a rosa branca do desespero, pois entre os objetos que o quarto consagra estão primeiro os objetos do corpo. (NASSAR, 2002, p. 9).

Assim adentramos no quarto de André, personagem narrador de Lavoura Arcaica, livro de Raduan Nassar. Penetramos no seu mundo, o mundo do filho desgarrado que consagra primeiro os objetos do corpo em detrimento a outros quaisquer. São os "olhos enfermiços" (NASSAR, 2002, p.20) de André que nos guiam dentro do enredo trágico do livro.

E me lembrei que a gente sempre ouvia nos sermões do pai que os olhos são a candeia do corpo, e que se eles eram bons é porque o corpo tinha luz, e se os olhos não eram limpos é que eles revelavam um corpo tenebroso, e eu ali, diante de meu irmão, respirando um cheiro

\footnotetext{
* Hugo Retamar é licenciado em Letras (habilitação em Português e Espanhol) pela UFRGS. Atualmente está vinculado a esta Instituição como aluno de licenciatura em Francês (segunda habilitação). Participa do grupo de pesquisa sobre "Gênero e História", coordenado pela professora Márcia Hoppe Navarro. Sua última publicação se encontra nos Anais do IX Congresso Internacional ABRALIC.
} 
exaltado de vinho, sabia que meus olhos eram dois caroços repulsivos.... (NASSAR, 2002, p. $15)$

É através destes olhos que eram "dois caroços repulsivos" (NASSAR, 2002, p.15), que conhecemos a verdadeira realidade da família interiorana de imigrantes árabes que escutava todos os dias ao redor da mesa o 'sábio sermão' do patriarca. É assim que conhecemos a família que só existia unida e que era sustentada pelos valores do Pai: a moderação, a humildade, a paciência em prol do bem estar e da união. A narrativa intimista de Raduan nos reporta, através das lembranças de André, a nossa própria infância, nos reporta à mesa posta tendo o pai à cabeceira e cada integrante da família em seu devido lugar, à casa solene onde ecoavam os discursos dos avós, o sentimento de comunhão, a sensação de perfeição da família calcada na segurança do pai, na afetividade da mãe e na sabedoria do avô, em suma nos mostra a força da Família. Creio que por isso a obra em questão me envolva tanto, porque vejo nela, com saudade, um pedaço de mim mesmo.

André, como já dito anteriormente, é o filho rebelde que cresce ouvindo com os olhos baixos, assim como os outros irmãos, a lavoura diária que é semeada pelo pai à mesa por meio de seus sermões, porém ao chegar à adolescência o jovem começa a querer levantar os olhos, começa a ter sede de luz, de vida, se descobre um indivíduo com vontades próprias, com sensações próprias, com desejos, ou seja, descobre que existia além do âmbito da família e que cada integrante desta não era simplesmente o todo, e sim era 'cada um' que se anulava, se refreava para que as vontades do pai se concretizassem. Os ímpetos eram contidos, as emoções refreadas e a este custo a ordem e a grandeza da família eram mantidas. Desde então, André passa a ver como falhos os sermões do pai e como falha aquela estrutura familiar na qual cada um escondia sua verdadeira vontade. No ímpeto de desfrutar dos prazeres tolhidos, de libertar-se dos sermões arcaicos, André foge para a cidade a fim de viver de seus próprios instintos 'sujos', foge para não contaminar a pureza da família e para fundar a sua própria igreja:

eu disse cegado por tanta luz tenho dezessete anos e minha saúde é perfeita e sobre esta pedra fundarei minha igreja particular, a igreja para o meu uso, a igreja que freqüentarei de pés descalços e corpo desnudo, despido como vim ao mundo, e muita coisa estava acontecendo comigo, pois me senti num momento profeta de minha própria história, não aquele que alça os olhos pro alto, antes o profeta que tomba o olhar com segurança sobre os frutos da terra, e eu pensei e disse sobre esta pedra me acontece de repente querer, e eu posso! (NASSAR, 2002, p. 89)

Os olhos de André o despertam ao desejar, ao querer, e assim, levado por essa sede de mais, de uma vida que o espera e que existe além do verbo do pai, uma vida que espera sua juventude cheia de desejos, seus olhos enfermiços, ele se afasta da família e ao fazê-lo descobre que também ele não existia sem esta: 


\begin{abstract}
Desde minha fuga, era calando minha revolta (tinha contundência o meu silêncio! Tinha textura a minha raiva!) que eu, a cada passo, me distanciava lá da fazenda, e se acaso distraído eu perguntasse "para onde estamos indo?" - não importava que eu, erguendo os olhos, alcançasse paisagens muito novas, quem sabe menos ásperas, não importava que eu, caminhando, me conduzisse para regiões cada vez mais afastadas, pois haveria de ouvir claramente de meus anseios um juízo rígido, era um cascalho, um osso rigoroso, desprovido de qualquer dúvida: estamos indo sempre para casa. (NASSAR, 2002, p. 36)
\end{abstract}

Após a partida a estrutura familiar se desestabiliza e com o intento de devolver à família, o filho pródigo, o irmão Pedro parte em busca da ovelha desgarrada. André vê-se frente aos 'olhos limpos' e 'puros' do irmão e os dois começam um diálogo com poucas palavras que pouco a pouco se soltam pelo poder do vinho. Pedro o discípulo do pai, começa também a sua 'lavoura'. André, frente a Pedro, vai construindo a sua imagem de rebeldia, e desnudando o real motivo de sua partida. Pouco a pouco no decorrer da conversa mantida entre os irmãos as máscaras caem, denunciam-se as hipocrisias e as meias verdades. André prefere assumir-se como o diabo, "propulsor de mudanças" (NASSAR, 2002, p. 40) ao Deus submisso dos sermões do pai, que era apenas um "promulgador de tábuas insuficientes" (NASSAR, 2002, p. 140). O diabo, em contraponto, é impaciente, é egoísta, impetuoso, sabe que existe o tempo de esperar e o tempo de agir, o diabo tem fome, se assume como sujeito de si mesmo, como fundador de sua igreja e como dono de suas vontades. Ana, a irmã de André, era a sua fome, e, assim como o narrador tinha ímpetos e vontades. Ana também era o diabo: "e não tardava Ana, impaciente, impetuosa, o corpo de campônia, a flor vermelha feito coalho de sangue prendendo de lado a lado os cabelos negros e soltos, essa minha irmã que, como eu, mais que qualquer outro em casa, trazia a peste no corpo..." (NASSAR, 2002, p. 31)

O incesto é revelado: Ana é o duplo de André. Ambos compartilhavam o mesmo lado esquerdo da mesa junto com a mãe e com Lula (o irmão caçula), o lado da destruição, do excesso de afetividade, de paixão, de vida, enquanto o que o lado direito era composto pelos discípulos do pai, pela moderação. Após o desabafo com o irmão e sabendo-se sem saída, sabendo que onde estivesse estaria sempre voltando para casa, para o mundo que era a sua casa, para Ana que era parte dele mesmo, para o seio da família, André decide voltar com Pedro à casa paterna e viver o destino que o esperava, como diziam as palavras do avô, "Maktub" (NASSAR, 2002, p. 91).

Ao retornar, o filho pródigo é recebido e banhado por suas irmãs, num ritual de purificação, isto é, André vinha do mundo, trazia na carne e principalmente nos olhos a enfermidade que crescia fora do santo ambiente familiar. O banho é representado como o batismo que purifica a alma e que a cura. 
Num primeiro momento, o jovem tem a primeira conversa com o pai, ou seja, é a primeira vez que fala com o pai sem ter os olhos baixos, sem estar submisso. André tenta contestar os sermões do pai, expor seus sentimentos, falar o que calou até o momento, liberar o tantas vezes silenciado pela força autoritária das palavras do pai e alertar-lhe da imprecisão de seus sermões, diz André:

- O amor que aprendemos aqui, pai, só muito tarde fui descobrir que ele não sabe o que quer;
essa indecisão fez dele um valor ambíguo, não passando hoje de uma pedra de tropeço; ao
contrário de que se supõe o amor nem sempre aproxima, o amor também desune; e não seria
nenhum disparate eu concluir que o amor na família pode não ter a grandeza que se imagina.
(NASSAR, 2002, p. 168)

Porém ao ouvir o filho assumir-se como possuidor do verbo, o pai o vê como enfermo, como cego, e assim André, pelo bem da família, decide conter-se e calar. Diante da mudança de posição de André, o pai o abençoa e decide festejar "aquele que estava cego e recuperou a visão" (NASSAR, 2002, p.171). A recuperação da visão de André só é possível, ao ver do pai, se este se resignasse à suas palavras, aos seus sermões incompletos, rígidos e que pregavam a circularidade, a não-liberdade, a não-constituição de uma identidade própria e individual, mas a manutenção do anonimato, da renúncia das vontades que constituía a ditadura familiar.

Ao iniciar-se a festa da chegada de André são mostradas as mesmas cenas do início do romance, dando-nos a impressão de circularidade no tempo desejada pelo pai. Ao retornar a casa paterna André se inseriria no seu contexto familiar e estaria reconstituída a união da família. Porém, uma simples mudança de tempos verbais nos dá a noção de que este tempo não é mais circular, quer dizer, ao enfrentar o seu destino André quebra o curso do tempo tornando-o "linear e irrecuperável" como diz Perrone-Moisés (1996). Na primeira festa temos verbos no imperfeito do indicativo, ou seja, tempo que denota um cenário, uma descrição, uma repetição e não um acontecimento: "até que a flauta voava de repente, cortando encantada o bosque, correndo na floração do capim e varando os pastos [...] e mais moças aguardavam a sua vez, todos eles batiam palmas reforçando o novo ritmo, e não tardava Ana, impaciente, impetuosa...” (NASSAR, 2002, p. 30)

Enquanto que na última festa temos:

até que a flauta voou de repente, cortando encantada o bosque, correndo na floração do capim e varando os pastos [...] e mais moças que aguardavam a sua vez, todos eles batiam palmas reforçando o novo ritmo, e quando menos se esperava, Ana (que todos julgavam sempre na capela) surgiu impaciente numa só lufada... (NASSAR, 2002, p. 188)

Os verbos se encontram no pretérito perfeito do indicativo, ou seja, um tempo de ação já concluída e que, por conseguinte, não tem mais volta. O destino já havia atuado sobre o tempo. 
Ana já não é mais a mesma da primeira festa, pois decidiu assumir-se como diabo, como a propulsora de mudanças. Ana faz o mesmo caminho de André ao pegar a maleta do irmão e vestir-se com as roupas das prostitutas demonstra sua condição de duplo de André. Os olhos de Ana assim como os do irmão 'viam demais', e por isso eram tão 'cegos' quantos os deste. Ana também não tinha lugar na família. Ao fim e ao cabo, o destino se cumpre, a fatalidade: Maktub.

A narrativa de Nassar é envolvente e repleta de uma atmosfera de sensualidade e de emoção, as metáforas são extremamente sensórias (a terra, o vinho) e fascinantes. Lavoura Arcaica não possui uma ordem convencional, pois está calcado nas lembranças de André, por isso mesmo, nos aprisiona e nos faz com que cheguemos ao mais profundo de nós mesmos para que possamos analisá-lo, e para isso não é necessário que sejamos descendentes de imigrantes árabes, ou que, tenhamos uma forte tradição religiosa como base. Basta que nos deixemos ser guiados pelos 'olhos turvos' e pelo 'verbo confuso' de André. No romance, me parece, temos dois pontos centrais que são justamente assim como as metáforas, já mencionadas anteriormente, sensórios. 'Os Olhos', e 'O Verbo'.

O primeiro é o responsável pelo desejo de ir além, de projetar-se ao desconhecido, de conhecer. É através dos olhos que desejamos, que selecionamos nossos desejos, que nos libertamos, os olhos são como diz em seu poema a poeta palestina Maria Ziady:

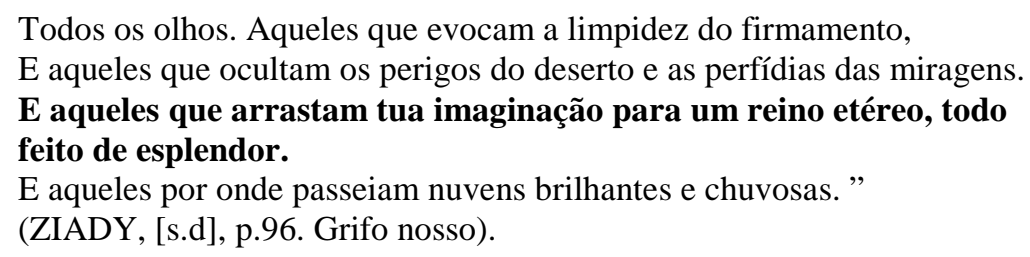

Por outro lado 'O verbo'. A palavra é a representação da autoridade e da constituição de uma identidade própria. Desde as sociedades mais antigas como a asteca, aquele que tinha o dom da palavra tinha um papel de destaque na sociedade, os chamados Tlatoani, ou, aquele que possui a palavra (TODOROV, 1993).

A palavra do pai na trama se constitui um poder capaz de anular, amedrontar e ao mesmo tempo unir baixo à lavoura diária os integrantes da família. A palavra de André por sua vez, após sua vivência fora do ambiente familiar passa a constituir sua identidade e se levanta contra a palavra repressora do pai. André através de seus olhos 'enfermiços' (segundo o lado direito da família) quis ir além, e através de sua palavra tentou mudar a microsociedade dentro da família, porém a palavra do pai, a lavoura semeada durante anos lhe produz a culpa que o faz retroceder. De qualquer forma suas atitudes já haviam instaurado a 
mudança e nada mais seria como antes, depois de conhecer um mundo além da família e do verbo do pai.

Sendo assim a palavra e os olhos constituem um poder que rege a sociedade e que também pode mudá-la. Deixemos então que nossos olhos também turvos e também cegos porque sedentos de luz, decifrem o mistério contido no verbo transformador de Raduan Nassar.

\section{Referências}

NASSAR, Raduan. Lavoura Arcaica. 3.ed. São Paulo: Schwarcz, 2002.

PERRONE-MOISÉS, Leyla. Da cólera ao silêncio. In: CADERNOS de Literatura Brasileira: Raduan Nassar, [Rio de Janeiro], n.2, Instituto Moreira Sales, set.1996. p.61-77.

TODOROV, Tzvetan. A conquista da América: a questão do outro. São Paulo: Martins Fontes, 1993.

ZIADY, Maria. Os olhos. In: CHALLITA, Mansour. As mais belas páginas da Literatura Árabe. Rio de Janeiro: Ingraf, [s.d.]. 